\title{
PENURUNAN AKTIVITAS FOSFATASE ASAM \\ DI DAERAH PERAKARAN BEBERAPA JENIS TANAMAN AKIBAT PERLAKUAN KAPUR DAN LIMBAH INDUSTRI BERTIMAH HITAM
}

\section{Decrease in Activity of Acid Phosphatase in Root-Zones of Several Plants} Driven by Lime and Lead-Containing Industrial Waste Treatments

\author{
Abdul Kadir Salam ${ }^{1}$, Vivin Arisanti ${ }^{2}$ dan Sri Yusnaini ${ }^{1} \quad \chi$ \\ ${ }^{1}$ Dosen dan ${ }^{2}$ Alumnus Jurusan IImu Tanah, Fakultas Pertanian, Universitas Lampung \\ Jl. Prof. Sumantri Brojonegoro No. 1, Bandar Lampung
}

\begin{abstract}
Heavy metals are potentially toxic to soil microorganims and are suggested to decrease soil enzymatic activities. Changes in activity of acid phosphatase in root-zones of some tropical plants treated with a lead-containing industrial waste was studied in a glasshouse experiment. Tropical soil sample (from Gedongmeneng and Banjaragung, Lampung) thoroughly treated with an electronics industrial waste at 0 to 40 ton ha ${ }^{-1}$ and lime at 0 or 5 ton $\mathrm{CaCO} 3 \mathrm{ha}^{-1}$ were cultured with corn (Zea mays L.), amaranth (Amaranthus tricolor L), and green kyllinga (Cyperus kyllinga). Changes in acid phosphatase activity, soil $\mathrm{Pb}$ concentration, and soil pH were measured after a 4 week growing period. Soil analysis showed that the activity of acid phosphatase was higher in Banjaragung soil than that in Gedongmeneng soil except in those cultured with green kyllinga. The activity of acid phosphatase was in general higher in the root-zone of corn than those in the root-zone of amaranth and green kyllinga. The activity of acid phosphatase in both soils decreased with waste addition regardless of plant grown. This was in a good correlation with the increase in soil available $\mathrm{Pb}$ as waste was added. However, the decrease in activity of acid phosphate as the soil pH increased by lime or waste addition suggested that the decrease in the phosphatase activity with waste addition was driven by the increase in soil $\mathrm{pH}$ rather than by the increase in soil available $\mathrm{Pb}$ with waste addition.
\end{abstract}

Keywords: industrial waste, lead, lime, phosphatase, tropical plants, tropical soils

\section{PENDAHULUAN}

Fosfatase merupakan salah satu enzim penting di dalam tanah. Karena berfungsi mempercepat perubahan P-organik menjadi ortofosfat, yang tersedia bagi tanaman, enzim ini memegang peranan penting dalam siklus biologis $P$ dalam sistem tanah, khususnya dalam hal menyediakan $P$ asal bahan organik bagi tanaman (Tabatabai, 1982). Oleh karena itu, pengetahuan tentang aktivitas fosfatase di dalam tanah serta berbagai faktor yang mempengaruhinya sangat penting dalam pengelolaan unsur hara tanaman di dalam tanah, khususnya $P$.

Salah satu faktor penting yang mempengaruhi aktivitas fosfatase di dalam tanah adalah kadar logam berat. Walaupun sebagian pakar kimia tanah melaporkan bahwa beberapa jenis logam berat dapat merangsang aktivitas enzim tanah
(Tate III, 1987), sebagian besar pakar menunjukkan bahwa pada konsentrasi relatif tinggi logam berat dapat menekan aktivitas enzim tanah termasuk fosfatase (Salam et al.. 1997a; Park et al., 1992; Stott et al., 1985; Juma dan Tabatabai, 1977). Juma dan Tabatabai (1977) melaporkan bahwa Cu, Fe, $\mathrm{Pb}, \mathrm{Cd}, \mathrm{Ni}$, dan $\mathrm{Zn}$ adalah logam berat yang dapat menghambat aktivitas fosfatase asam yang, dengan penambahan $25 \mu \mathrm{mol} \mathrm{kg}^{-1}$ tanah menurunkan aktivitas enzim tersebut sebesar $18.7-47.7 \%$. Derajat penambahan logam dalam penelitian mereka memang cukup tinggi, namun amatan tersebut dengan jelas menunjukkan pengaruh negatif logam berat terhadap aktivitas fosfatase di dalam tanah yang tercemar logam berat. Mathur et al. (1980) juga melaporkan bahwa aktivitas fosfatase dan mikroorganisme di tanah Histosol dengan konsentrasi $\mathrm{Cu}$ tinggi lebih rendah daripada dengan konsentrasi $\mathrm{Cu}$ rendah.

Salam, A.K., V. Arisanti, dan S. Yusnaini. 1999. Penurunan aktivitas fosfatase asam di daerah perakaran beberapa jenis tanaman akibat perlakuan kapur dan limbah industri bertimah hitam. J.II. Tan.Lingk. 2(1):1-6. 
Salam et al. (1997a) juga melaporkan bahwa penambahan $\mathrm{Cd}$ dan $\mathrm{Pb}$ masing-masing dengan takaran $40 \mathrm{mg} \mathrm{kg}^{-1}$ menurunkan aktivitas fosfatase asam masing-masing sebesar $44 \%$ dan $54 \%$ dalam sebuah tanah Jepang dan sebesar $43 \%$ dan $39 \%$ dalam sebuah tanah Indonesia. Pengaruh negatif logam berat terhadap aktivitas enzim lain juga telah dilaporkan (Reddy dan Faza, 1989; Reddy et al., 1987).

Pakar kimia tanah menjelaskan bahwa menurunnya aktivitas enzim tanah akibat keberadaan logam berat dalam konsentrasi tinggi dapat terjadi paling tidak melalui dua mekanisme penting (Salam et al., 1997a). Pertama, secara tidak langsung logam berat menekan populasi mikroorganisme penghasil fosfatase (Huysman et al., 1994; Fließbach et al., 1994; Baath, 1989). Menurunnya populasi mikroorganisme ini selanjutnya mengakibatkan menurunnya produksi fosfatase di dalam tanah. Kedua, kation logam berat dapat secara langsung berasosiasi membentuk ikatan koordinasi dengan molekul enzim yang berfungsi sebagai agen pengkelat. Asosiasi ini mengakibatkan reaktivitas molekul enzim menurun dan akibatnya aktivitas enzim tersebut di dalam tanah menurun (Tate III, 1987).

Penelitian ini bertujuan mempelajari perubahan aktivitas fosfatase asam di daerah perakaran beberapa jenis tanaman yang ditumbuhkan di dua jenis tanah dengan kapasitas jerap berbeda terhadap logam berat dan diberi perlakuan kapur dan limbah industri elektronika yang mengandung $\mathrm{Pb}$ dalam konsentrasi relatif tinggi.

\section{BAHAN DAN METODE}

Contoh tanah diambil dari horizon Ap tanah Banjaragung (Lampung Tengah) dan Gedongmeneng (Bandar Lampung). Telah dilaporkan sebelumnya bahwa tanah Banjaragung memiliki daya jerap terhadap logam berat lebih tinggi daripada tanah Gedongmeneng (Salam et al., 1997b). Setelah pengambilan, contoh tanah dikering-udarakan, dihaluskan, diayak tembus diameter $2 \mathrm{~mm}$ dan diaduk rata. Beberapa sifat fisika dan kimia kedua jenis tanah tersebut disajikan pada Tabel 1. Untuk setiap satuan percobaan (SP) digunakan contoh tanah sebanyak $400 \mathrm{~g}$ (setara berat kering oven $\left.105^{\circ} \mathrm{C}\right)$.

Perlakuan disusun secara faktorial dengan 3 ulangan. Faktor perlakuan pertama adalah limbah industri elektronika, yang diberikan dalam 4 tingkat: $0,2,4$, dan $8 \mathrm{~g}$ per SP atau masing-masing setara dengan $0,10,20$ dan 40 ton $\mathrm{ha}^{-1}$. Limbah industri diperoleh dari Unit Pengolahan Limbah PT Indomacin Jakarta dan diambil oleh petugas dari Kantor Pengkajian Perkotaan dan Lingkungan (KPPL) DKI Jakarta. Limbah terse-but mengandung $130 \mathrm{ppm} \mathrm{Pb}$ dan logam berat lain dalam konsentrasi relatif rendah (Salam et al., 1996). Faktor perlakuan kedua adalah kapur, yang diberikan dalam 2 tingkat, yaitu: 0 dan $1 \mathrm{~g} \mathrm{CaCO}_{3}$ per SP atau masing-masing setara dengan 0 dan 5 ton $\mathrm{CaCO}_{3} \mathrm{ha}^{-1}$.

Setelah dicampur rata dengan bahan perlakuan, contoh tanah dimasukkan ke dalam pot plastik dengan ukuran $500 \mathrm{~g}$, kemudian diinkubasi pada kadar air $40 \%(\mathrm{v} / \mathrm{w})$ dalam suhu ruang. Setelah satu minggu, sebanyak 2 bibit tanaman yang telah dipersiapkan sebelumnya (Arisanti, 1998) dipindahkan ke dalam setiap satuan percobaan. Tanaman dipelihara selama 4 minggu di dalam rumah kaca. Penyiraman dilakukan seperlunya untuk mempertahankan kadar air tanah tidak berada jauh dibawah kapasitas lapang. Pupuk dasar (urea, SP-36, dan $\mathrm{KCl}$ ) diberikan pada saat tanam masingmasing dengan takaran $0.02 \mathrm{~g}$ per SP atau setara dengan $100 \mathrm{~kg} \mathrm{ha}^{-1}$

Tabel 1. Beberapa sifat fisika dan kimia tanah Gedongmeneng dan tanah Banjaragung

\begin{tabular}{clcc}
\hline No. & Sifat tanah & Gedongmeneng & Banjaragung \\
\hline 1. & Tekstur (\%) & 45,6 & \\
& - Pasir & 19,6 & 22,0 \\
& - Debu & 34,8 & 21,2 \\
& - Liat & 5,25 & 56,8 \\
2. & pH $\left(\mathrm{H}_{2} \mathrm{O} \mathrm{1:2,5)}\right.$ & 5,10 & 5,13 \\
3. & KTK $\left(\mathrm{cmol}(+) \mathrm{kg}^{-1}\right)$ & 2.06 & 7,34 \\
4. & C-organik (\%) & 0,13 & 1,84 \\
5. & N-total (\%) & 15,8 & 0,17 \\
6. & Nisbah C/N & 2,5 & 10,8 \\
7. & P-tersedia $\left(\mathrm{mg} \mathrm{kg}^{-1}\right)$ & 15,2 \\
\hline
\end{tabular}


Dalam penelitian ini digunakan 3 jenis tanaman uji dalam percobaan sejenis, yaitu jagung (Zea mays L.), bayam cabut (Amaranthus tricolor L.), dan rumput teki (Cyperus kyllingia), masingmasing mewakili golongan tanaman pangan, sayuran, dan gulma.

Contoh tanah dari daerah perakaran tanaman diambil pada saat tanaman berumur 4 minggu sejak dipindahkan ke dalam SP. Ketersediaan $\mathrm{Pb}, \mathrm{pH}$ tanah, dan aktivitas enzim tanah ditetapkan dalam keadaan lembab. Ketersediaan $\mathrm{Pb}$ ditetapkan dengan cara DTPA (Baker dan Amacher, 1982); pH dengan elektroda gelas, dan aktivitas fosfatase asam dengan cara Tabatabai (Tabatabai, 1982) yang telah dimodifikasi (Salam et al., 1998).

\section{HASIL DAN PEMBAHASAN}

Perubahan aktivitas enzim fosfatase asam di daerah perakaran beberapa jenis tanaman akibat perlakuan limbah industri dan kapur disajikan pada $\mathrm{Gb} .1$, sedangkan perubahan $\mathrm{pH}$ tanah dan ketersediaan $\mathrm{Pb}$ akibat perlakuan yang sama masing-masing disajikan pada $\mathrm{Gb} .2$ dan Gb.3.

Aktivitas fosfatase asam dalam tanah Banjaragung lebih tinggi daripada dalam tanah Gedongmeneng, kecuali dalam tanah yang ditanami rumput teki. Secara umum aktivitas fosfatase asam di daerah perakaran tanaman secara umum menurun dengan penambahan limbah industri, terlepas dari jenis tanamannya (Gb.1), sejalan dengan meningkatnya ketersediaan $\mathrm{Pb}$ asal limbah industri tersebut (Gb.3). Penambahan kapur secara konsisten menurunkan aktivitas fosfatase asam di daerah perakaran tanaman (Gb.1). Penambahan limbah industri secara konsisten juga meningkatkan $\mathrm{pH} \operatorname{tanah}(\mathrm{Gb} .2$ ).

Menurunnya aktivitas fosfatase asam dengan penambahan limbah industri bertimah hitam dapat disebabkan oleh beberapa mekanisme. Pertama, $\mathrm{Pb}$ asal limbah industri secara tidak langsung menurunkan aktivitas fosfatase melalui penekanan populasi mikroorganisme penghasil fosfatase. Telah dilaporkan sebelumnya bahwa beberapa jenis logam berat bersifat toksik bagi mikroorganisme (Huysman et al., 1994; Fließbach et al., 1994; Baath, 1989). Kedua, seperti dinyatakan oleh Tate III (1987), kation logam berat dapat membentuk ikatan koordinasi dengan molekul enzim dan mengakibatkan reaktivitas enzim menurun dan tidak dapat berpartisipasi dalam reaksi biokimia yang mestinya dikatalisasi oleh enzim tersebut. Akibatnya, aktivitas fosfatase di dalam tanah menurun dengan meningkatnya ketersediaan $\mathrm{Pb}$.

Namun demikian, meningkatnya $\mathrm{pH}$ tanah dengan bertambahnya takaran limbah industri (Gb.2) memunculkan penafsiran lain, sebab peningkatan $\mathrm{pH}$ tanah akibat pengapuran ternyata secara drastis juga menurunkan aktivitas fosfatase (Gb.1 dan Gb.2). Hal ini menunjukkan bahwa penurunan aktivitas fosfatase tersebut (Gb.1) juga diakibatkan oleh peningkatan $\mathrm{pH}$ tanah. Pengaruh $\mathrm{pH}$ tanah yang drastis terhadap penurunan aktivitas fosfatase menunjuk-kan bahwa penurunan tersebut lebih diakibatkan oleh peningkatan $\mathrm{pH}$ daripada oleh peningkatan ketersediaan $\mathrm{Pb}$.

Telah banyak dilaporkan sebelumnya bahwa perubahan $\mathrm{pH}$ dapat mengakibatkan perubahan aktivitas fosfatase. Beberapa peneliti menunjukkan bahwa aktivitas fosfatase meningkat dengan meningkatnya $\mathrm{pH}$ tanah sampai suatu nilai optimum tercapai (pH optimum adalah $\mathrm{pH}$ saat aktivitas fosfatase tanah mencapai maksimum) dan menurun di atas $\mathrm{pH}$ optimum (Salam et al., 1998; Frankenberger Jr. dan Johanson, 1982). Perubahan ini diakibatkan oleh reaksi bolak-balik yang melibatkan ionisasi dan deionisasi gugus asam dan basa pada bagian aktif protein dari enzim (Frankenberger Jr. dan Johanson, 1982). Namun demikian, penurunan aktivitas fosfatase dengan meningkatnya $\mathrm{pH}$ tanah secara tidak langsung dapat pula diakibatkan oleh terganggunya aktivitas mikroorganisme sejalan dengan peningkatan $\mathrm{pH}$, sebab $\mathrm{pH}$ merupakan salah satu faktor utama yang juga mempengaruhi aktivitas mikroorganisme di dalam tanah.

\section{KESIMPULAN}

Aktiivitas fosfatase asam dalam tanah Banjaragung lebih tinggi daripada dalam tanah Gedongmeneng, kecuali dalam tanah yang ditanami rumput teki. Aktiivitas fosfatase asam secara umum lebih tinggi di daerah perakaran jagung daripada di daerah perakaran bayain cabut dn rumput teki. Aktivitas fosfatase asam di daerah perakaran menurun dengan penambahan limbah industri elektronika, terlepas dari jenis tanaman yang digunakan. dan berkorelasi dengan peningkataı ketersediaan $\mathrm{Pb}$ sejalan dengan bertambahnya takaran limbah industri. Namun demikian. menurunnya aktiivitas fosfatase asam dengan meningkatnya $\mathrm{pH}$ tanah akibat pengapuran dan 
penambahan limbah industri dapat menunjukkan bahwa penurunan aktivitas fosfatase dengan bertambahnya takaran limbah industri tersebut lebih diakibatkan oleh meningkatnya pH tanah, bukan oleh meningkatnya ketersediaan $\mathrm{Pb}$ akibat perlakuan limbah industri.

\section{UCAPAN TERIMAKASIH}

Penelitian ini sebagiannya didukung oleh dana penelitian dari Direktorat Jenderal Pendidikan Tinggi, Departemen Pendidikan dan Kebudayaan melalui Program Hibah Bersaing (HB IV/3) Tahun Anggaran 1997/1998. Atas dukungan dana tersebut diucapkan terimakasih.

\section{DAFTAR PUSTAKA}

Arisanti, V. 1998. Aktivitas fosfatase asam di daerah perakaran tanaman jagung (Zea mays L.), Bayam (Amaranthus tricolor L.), dan Gulma Teki (Cyperus kyllingia Endl.) yang diperlakukan dengan limbah industri elektronika dan kapur pada tanah Oxisol dan Alfisol. Skripsi Sarjana. Fakultas Pertanian Universitas Lampung, Bandar Lampung.

Baath, E. 1989. Effects of heavy metals in soil on microbial processes and populations (a review). Water Air Soil Pollut., 47:335-379.

Baker, D.E. and M.C. Amacher. 1982. Nickel, copper, zinc, and cadmium. p. 323-336 in A.L. Page, R.H. Miller, and D.R. Keeney (Eds.). Methods of Soil Analysis Part 2: Chemical and Microbiological Properties. $2^{\text {nd }}$ ed. SSSA Inc., Madison.

Fließbach, A., R. Martens, and H.H. Reber. 1994. Soil microbial biomass and microbial activity in soils treated with heavy metalcontaminated sewage sludge. Soil Biol. Biochem., 26:1201-1205.

Frankenberger Jr. W.T., and J.B. Johanson. 1982. Effect of pH on enzyme stability in soils. Soil Biol. Biochem., 14:433-437.

Huysman, F., W. Verstraete, and P.C. Brookes. 1994. Effect of manuring practices and increased copper concentrations on soil microbial populations. Soil Biol. Biochem., 26:103-110

Juma, N. G. and M. A. Tabatabai. 1977. Effects of trace elements on phosphatase activity in soils. Soil Sci. Soc. Am. J., 41:343-346.
Mathur, S.P., J.I. MacDougall, and M. McGrath. 1980. Levels of activities of some carbohydrase, protease, lipase, and phosphatase in organic soils of differing copper content. Soil Sci., 129:376-385.

Park, S.C., T.J. Smith, and M.S. Bisesi. 1992. Activities of phosphomonoesterase and phosphodiesterase from Lumbricus terrestris. Soil Biol. Biochem., 24:873-876.

Reddy, G.B., A. Faza, and R. Bennet, Jr. 1987. Activity of enzymes in rhizosphere and nonrhizosphere soils amended with sludge. Soil Biol. Biochem., 19:203-205.

Reddy, G.B. and A. Faza. 1989. Dehydrogenase activity in sludge amended soil. Soil Biol. Biochem., 21:327

Salam. A.K., S. Djuniwati, J.T. Harahap dan Suwarto. 1996. Imobilisasi logam berat asal limbah industri di dalam tanah tropika: 1. Sifat kimia limbah industri. J. IImiah II. Pert., 4(1):61-67.

Salam. A.K., S. Djuniwati, dan Sarno. 1997b. Lowering heavy metal solubilities in tropical soils by lime and cassava-leaf compost additions. Proc. Environ. Technol. Manag. Sem. (dalam pencetakan).

Salam. A.K., A. Katayama, and M. Kimura. 1997a. The activity of soil acid-phosphatase at elevated concentrations of heavy metals. J. Teknik Lingk., 3(1).7-12.

Salam. A.K., A. Katayama, and M. Kimura 1998. Activities of some soil enzymes in different land use systems after deforestation in hilly areas of West Lampung, South Sumatra, Indonesia. Soil Sci. Plant Nutr. 44:93-103.

Stott, D.E., W.A. Dick, and M.A. Tabatabai 1985. Inhibition of pyrophosphatase activity in soils by trace elements. Soil Sci., 139:112117.

Tabatabai, M.A. 1982. Soil enzymes. p. 903-947 in A.L. Page, R.H. Miller, and D.R. Keeney (Eds). Methods of Soil Analysis Part 2: Chemical and Microbiological Properties. $2^{\text {nd }}$ ed. Soil Sci. Soc. Am., Inc., Madison.

Tate III R.L. 1987. Soil Organic Matter Biological and Ecological Effects. John Wiley \& Sons, New York. 


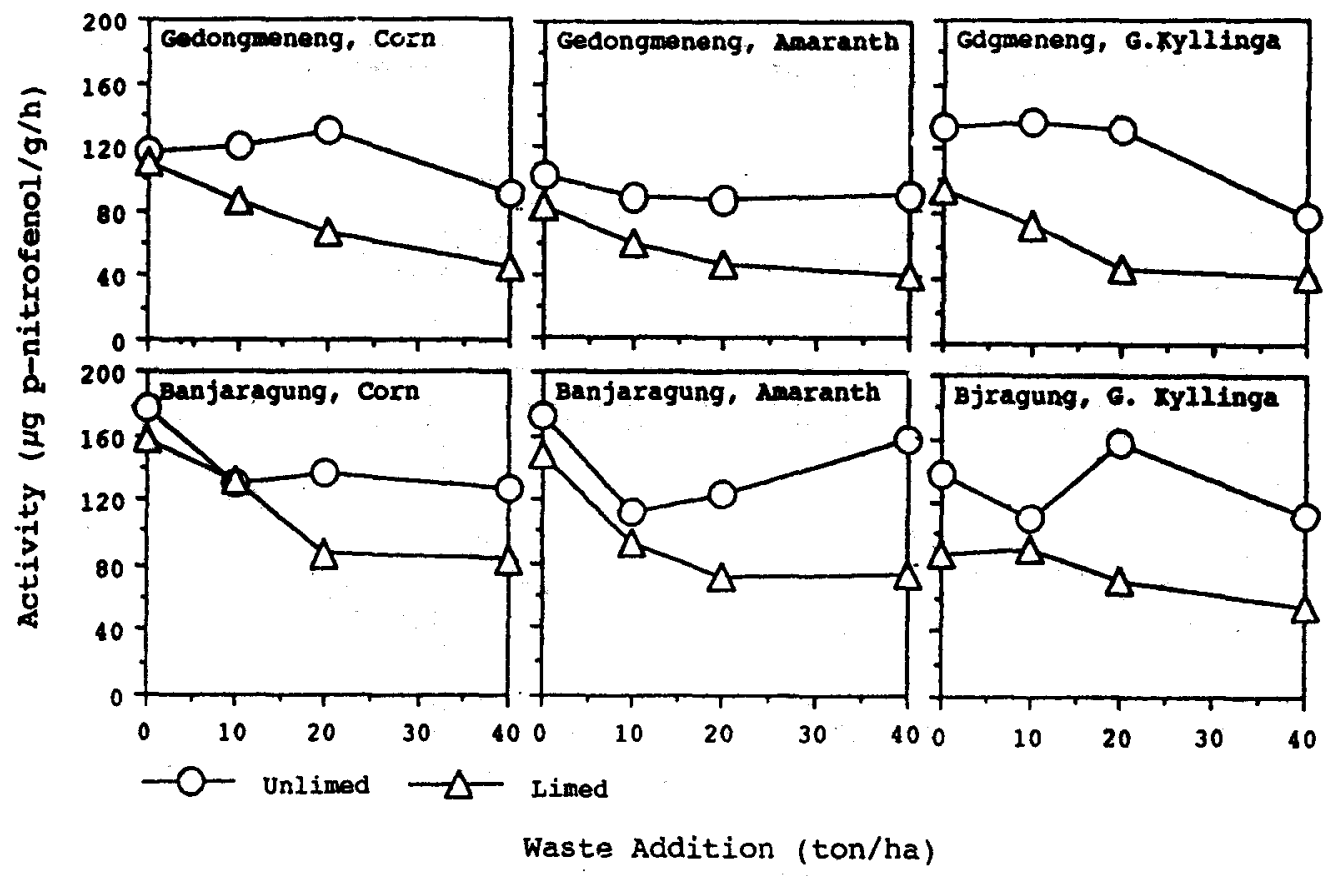

Gambar 1. Perubahan aktivitas fosfatase asam di daerah perakaran beberapa jenis tanaman akibat penambahan imbah industri elektronika dan kapur

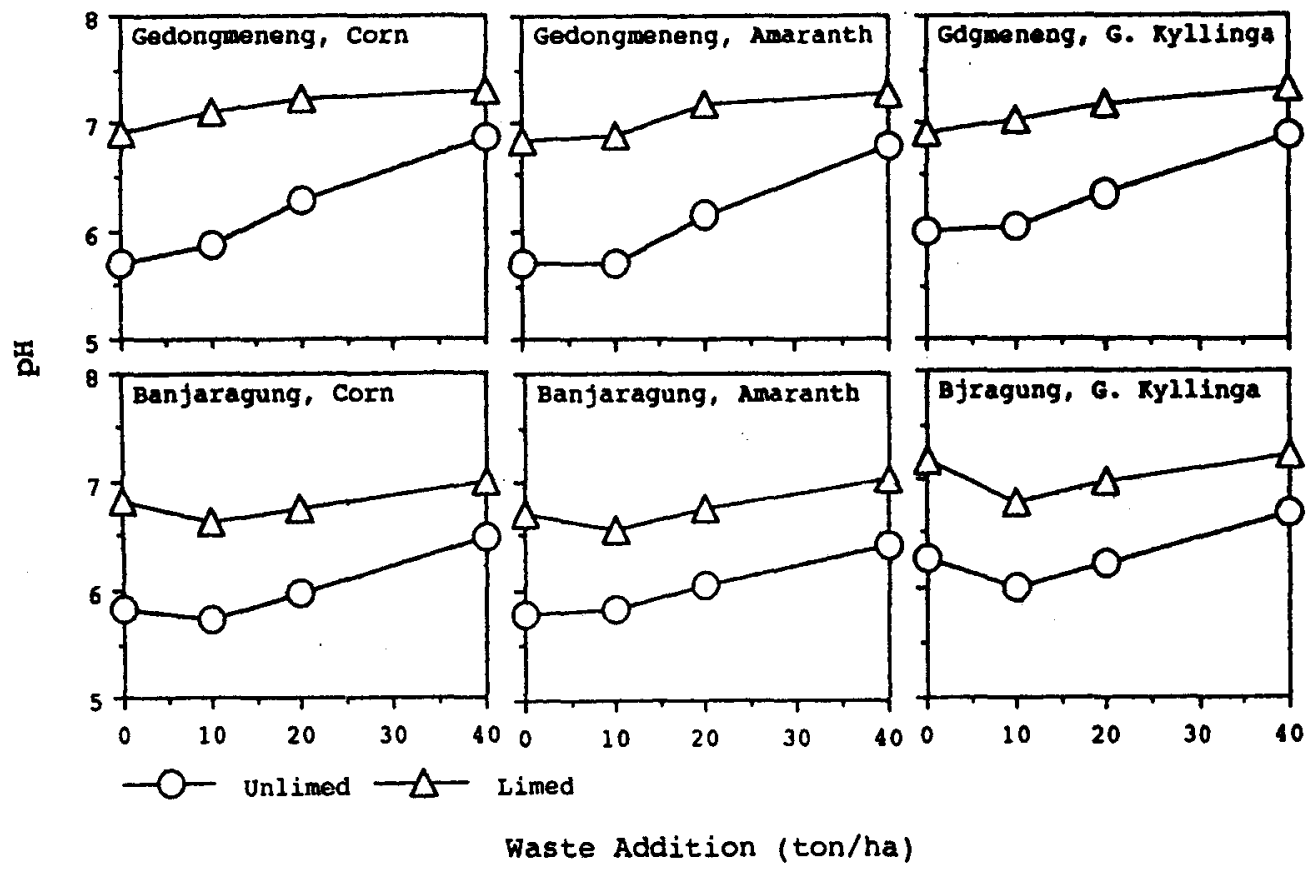

Gambar 2. Perubahan pH tanah di daerah perakaran beberapa jenis tanaman akibat penambahan limbah industri elektronika dan kapur 


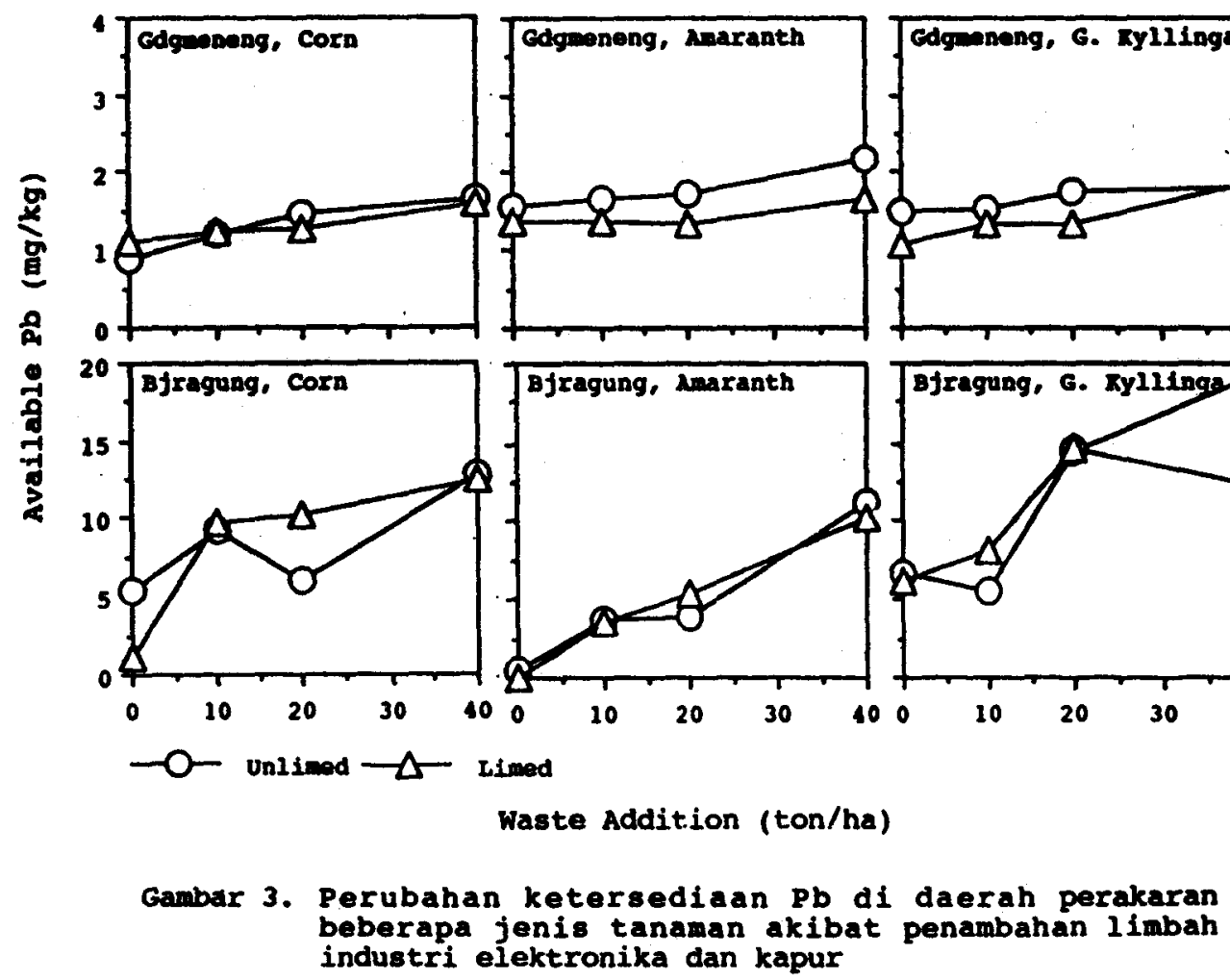

